\title{
ISCHAEMIC CONTRACTURES OF THE LOWER LIMB
}

By H. Ellis, M.Ch., F.R.C.S. Senior Surgical Registrar, The Radcliffe Infirmary, Oxford

Post-traumatic contractures of the foot as well as of the hand were described by Volkmann himself but, in spite of the considerable literature concerning the aetiology and treatment of the upper limb contractures which go by his name, the subject of ischaemic deformities of the leg has received comparatively little attention. The following paper briefly reviews the features of this well defined and not uncommon syndrome.

\section{Aetiology of Volkmann's Contracture}

There is no doubt that post-traumatic contractures of muscles are ischaemic in origin but for many years the exact nature of the vascular obstruction remained the subject of debate.

Volkmann considered the syndrome to be due to arterial blockage resulting from tight splinting but Murphy (1914) believed that venous obstruction was the cause of the ischaemia; this theory was supported by the experimental work of Brookes (1922) and Middleton (1930). Later animal studies by Wilson (1932), Griffiths (1940), Barnes and Trueta (1942), Clarke (1946) and others, however, strongly indicated that arterial occlusion is the important aetiological factor. Moreover, it has been shown clinically that a purely arterial obstruction, an embolus, for example, may result in the development of a histologically confirmed Volkmann's contracture (Griffiths, 1940).

Complete arterial obstruction for a period of approximately 24 hours is sufficient to produce necrosis of all the soft tissues of the limb with a resulting macroscopic gangrene. A period of 8 to 12 hours occlusion, although usually insufficient to cause cutaneous gangrene, is enough to precipitate ischaemia in the more oxygendependent muscles (Harman, 1947), and aseptic necrosis may then occur. Fibrous replacement of the dead tissue will then take place and subsequent contracture of this fibrous tissue accounts for the deformities of the established Volkmann.

The arterial supply to muscle is by an end-artery system (Blomfield, I945; Le Gros Clark, 1945) and localized injury to these vessels may be followed by muscle necrosis even in the absence of damage to major arteries. The presence of peripheral pulses in a traumatized limb is thus no guarantee that ischaemic changes will not take place.

Although the importance of arterial injury has been stressed, it should not be overlooked that venous occlusion can produce undoubted ischaemia by damming back the arterial supply to the soft tissues. During the Korean war examples of gangrene were reported following extensive venous damage only, the arterial tree being found intact at subsequent dissection of the amputated limbs (Hughes, 1954; Spencer and Grew, 1955).

The Clinical Features of Ischaemic contractures in the Lower Limb

Contractures of the lower limb may occur within 24 hours of injury (Macfarlane, 1942). However, the deformities often remain unnoticed during the period that the limb remains immobilized in plaster or in traction, only to become evident when the patient becomes fully ambulant again weeks or even months after injury.

The fully established clinical picture is quite typical and comprises an equino-cavo-varus deformity of the foot, limitation of movement of the subtaloid and mid-tarsal joints, clawing of the toes and Hallux flexus (Fig. I). These deformities may occur alone or in combination, and result from the contractures of the ankle and toe flexor muscles overcoming those of the weaker extensor group. Lapeyre and Carabalona (I952) have, however, recorded an unusual example in which contractures occurred with deformity in dorsiflexion. The muscles in the affected limb may be indurated, wasted, and may eventually undergo massive calcification (Albert and Mitchell, 1943).

Apart from contractures, the limb may show other evidence of vascular impairment. The foot may be cyanosed with a sluggish cutaneous circulation, as indicated by the rate of colour return after blanching with finger pressure and by Buerger's 


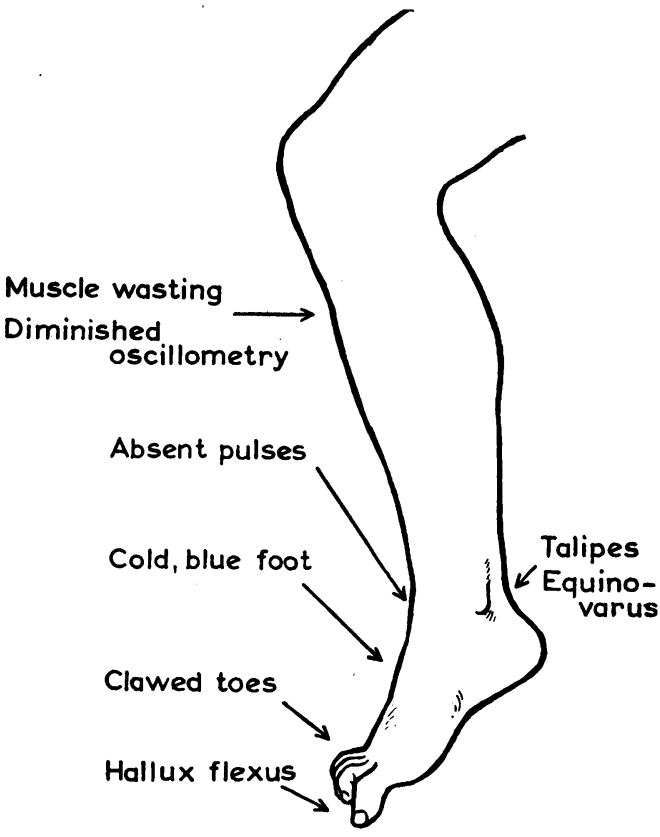

Clinical features which may be present in ISCHAEMIC CONTRACTURE of the lower limb. -

test. There may be trophic ulceration or even frank cutaneous gangrene. Peripheral pulses may be diminished or absent and oscillometry is usually depressed. In some cases the peripheral nerves are affected by the ischaemia; hyperaesthesia or stocking anaesthesia may then be found (Parkes, 1945; Stanford, 1944).

\section{Types of Lesion Producing Lower Limb Contractures}

Ischaemic contractures of the lower limb may result from a wide variety of vascular injuries. Examples have been recorded following femoral fractures (Burdzik, 1953; Horwitz, 1940; Riche et al., 1939), tibial fractures (Clark, 1943; MacFarlane, 1942; Salembier, 1954; Sirbu et al., 1944), traumatic aneurysm of the posterior tibial artery (Fellander, 1949), soft tissue injuries (Jones and Cotton, 1935), rupture of the popliteal artery (Horn and Sevitt, 195I), intra-arterial injections (Lapeyre and Carabalona, 1952) and femoral embolism (Griffiths, 1940).

Of considerable interest and importance are the contractures developing in the normal limb of children under treatment for femoral shaft fractures by means of suspending both legs in ' gallows ' traction (Miller et al., 1952; Thompson and Mahoney, r95I). Here, the vascular damage is probably due to tight bandaging rather than traction, although there is good evidence, both clinical and experimental, that powerful traction may induce vascular spasm and precipitate ischaemic changes in the limb; Mustard and Simmons (1953), for example, were able to produce spasm of the arterial tree of both the affected and the contra-lateral leg by means of wide fracture distraction in the lower limb of the dog, Simmons (1956) has recorded three examples of contractures resulting from the forcible traction of corrective osteotomies and it is not rare to observe temporary loss of the peripheral pulses following fracture manipulations (Cohen, 1944).

\section{The Anterior Tibial Syndrome}

An interesting condition, closely related to ischaemic contractures following vascular injury in the lower limb, is the anterior tibial syndrome, first described by Sirbu and his colleagues in 1944 . Following unaccustomed exercise, minor trauma or a minor operation on the leg, the patient develops painful swelling, oedema, induration and redness over the anterior tibial compartment. This may be followed by a dropped foot deformity, limitation of plantar flexion and contractures of the toe extensors. There may or may not be an associated lesion of the anterior tibial nerve with sensory impairment or anaesthesia in the small triangular area proximal to the first interdigita cleft and with weakness of extensor digitorum brevis. Muscle biopsies have confirmed that the condition is due to infarction of the muscles in the anterior tibial group (Carter et al., 1949) and, indeed, frank gangrene of these muscles has been recorded (Phalen, I948).

The probable mechanism of this phenomenon has been attributed by Carter et al. (1949), to the increased pressure within the tight subfascial space of the anterior tibial compartment. This may result from swelling of muscles in unaccustomed exercise which may be aggravated by the rupture of some muscle fibres and consequent haemorrhage. The raised pressure, by occluding the small vessels supplying the muscles, is thought to precipitate ischaemic necrosis. The associated anterior tibial nerve lesion may be due to its compression (with subsequent rapid recovery) or its ischaemia (with a much less favourable prognosis). As regards treatment of this condition, bed-rest in mild cases may be followed by complete recovery but in severe examples, with associated paralysis, immediate decompression by fasciotomy is indicated (Sirbu, et al., 1944).

The Incidence of Volkmann's Ischaemia in the Lower Limb

Meyerding (1930), in reviewing 128 patients with Volkmann's contracture treated at the Mayo 
Clinic, recorded only three cases occurring in the lower limb and Horwitz was able to add only 15 more examples in the literature up to 1940 . Since that time, cases have been reported with increasing frequency and it seems likely that this phenomenon is commoner than has hitherto been supposed (Watson Jones, 1952).

No author has previously recorded the actual incidence of Volkmann's contracture following lower limb injuries but the present writer found nine examples (2.7 per cent.) in a series of 343 consecutive tibial fractures in adult patients (Ellis, I 958). These cases varied from those with mild clawing of the toes to those with the gross and crippling deformities of severe ischaemic contractures. Seven of the patients had marked limitation of foot and/or ankle movement and these accounted for no less than one-third of the patients in the whole series with persistent severe impairment of function.

\section{Treatment}

Prophylaxis naturally includes the avoidance of tight splints and excessive traction, care in the application of plaster bandages to the injured limb, and gentle manipulation of the fracture. Where there is an open wound, wide fasciotomy is indicated in order to avoid subfascial tension consequent upon post-traumatic swelling. Even in closed injuries, early fasciotomy may be required where severe swelling threatens to jeopardise the circulation in the limb (Linder and Harley, 1953).

When there is clinical evidence of vascular damage following a lower limb injury, any external constriction from bandages or plaster must be relieved. The fracture, if unreduced, should be carefully manipulated into alignment since it may be that a major artery is being stretched over a sharp bone end, an occurrence which has been demonstrated arteriographically (Ellis, 1958). The blood pressure, if low, must be restored to normal by blood transfusion since a low pressure will further impair the circulation in the damaged limb.

If there is doubt about the exact localization of the vascular injury, femoral angiography is useful (Griffiths, 1948) and can readily be carried out by percutaneous puncture. Above the popliteal bifurcation, a vascular tear may be sutured, or a segment of damaged artery replaced by a graft (fortunately, each patient carries his own ' artery bank' with him, since the autonomous saphenous vein graft proved quite satisfactory in the Korean campaign). Below the popliteal bifurcation, repair is difficult and of doubtful value; the torn artery is best ligated.

If arterial spasm only is found at exploration, Procaine may be injected into and around the vessel, but the local application of 2.5 per cent. Papaverine is preferable and is strongly advocated by Kinmonth (1952).

Wide fasciotomy, as already noted, is indicated, to reduce subfascial tension and, to this end, the injection of Hyalase may help disperse traumatic oedema (Macausland et al., I953).

The place of sympathetic block and lumbar sympathectomy in cases of acute vascular damage is still under discussion. Learmonth (1943) pointed out that traumatic arterial spasm may persist in an amputated limb completely deprived of its nerve supply, but many surgeons of considerable experience in vascular trauma are convinced that sympathetic interuption is of value (Griffiths, 1948), since even if the artery in spasm is not relaxed, collateral branches will be opened fully.

In the established case, with severe deformities, various orthopaedic measures may be of value, for example, elongation of the tendo Achilles for plantar flexion deformity and Keller's operation for Hallux flexus.

Recently Seddon (1956) has recorded good results in late cases from excision of the fibrotic mass of avascular tissue followed, where necessary, by reconstructive procedures such as tendon transplants. Although his report was mainly concerned with forearm contractures, three of his cases were Volkmann's contractures of the lower limb involving the calf muscles.

\section{Summary}

Ischaemic contractures in the lower limb are seldom reported but are probably not rare. An incidence of 2.7 per cent. was found in a large series of tibial fractures studied by the author.

The pathology, clinical features and treatment of the condition, and of the related anterior tibial syndrome, are discussed.

\section{Acknowledgment}

I would like to thank Mr. F. W. Holdsworth for permission to study the patients with fractures of the tibial shaft under his care at the Royal Infirmary, Sheffield.

\section{BIBLIOGRAPHY}

ALBERT, M., and MITCHELL, W. R. D. (1943), Lancet, i, 5 r9. BARNES, J. M., and TRUETA, J. (I942), Brit. F. Surg., 30, 74. BLOMFIELD, L. B. (1945), Proc. roy. Soc. Med., 38, 617. BROOKES, B. (1922), Arch. Surg. (Chicago), 5, 188. BURDZIK, G. (1953), Z. Orthop., 83, 400. CARTER, A. B., RICHARDS, R. L., and ZACHARY, R. B.
(I949), Lancet, ii, 928.

CLARK, C. W. (1943), Brit. med. F., ii, 167.

CLARKE, W. T. (1946), Canad. med. Ass. F., 54, 339.

COHEN, S. M. (1944), Lancet, i, I.

ELLIS, H. (In Press).

FELLANDER, M. (1949), Acta Chir. scand., 98, 530.

Bibliography continued on page 488 
cause of the contamination and one in which this organism plays a special role. It is much more likely that it has a host relationship which is specific among normal intestinal organisms, and which enables it alone to invade the blood stream in sufficient numbers and over a long enough period to be detected moderately frequently by random blood culture. It is reasonable to assume that this invasion is facilitated by insults to the reticuloendothelial system, such as T.A.B. inoculation (case I), the virus of infective hepatitis (case 6), which was combined with yellow fever inoculation in case 5 , and perhaps the results of cardiac failure (cases 9 to 15 ). Damage to the bowel wall (cases 3 and 4) due to dysentery is another possibility, but it remains to stress that these postulated causes are far more frequent than the condition they are called on to explain.

\section{Conclusion}

The incidence of Bact. alkaligenes bacillaemia is much greater than is commonly realized. The organism is not a contaminant of blood cultures.
Occasionally capable of causing serious disease, it is usually a secondary invader and often innocuous, $\bar{z}$ but in a given case one is not justified in assuming that it will necessarily have no adverse clinical. effects.

\section{Summary}

Seventeen unselected cases are described in which Bact. alkaligenes was isolated from the blood. $\overline{\mathrm{D}}$ The clinical significance of this series of cases is discussed and conclusions are drawn.

I am grateful to my clinical colleagues in all $\overrightarrow{0}$ cases for the clinical details.

\section{BIBLIOGRAPHY}

ANDERSON, W. K. (1933), Practitioner, 131, 102. BANERJEE, J. B., and SARKER, J. K. (1949), Indian med. Gaz., 84, 384.

HALL, G., and GARVAN, J. (1949), Med. F. Aust., 2, 68 r.

LIBRACH, I. M. (1954), Postgrad. med. F., 30, 424.

RAVENAL, M. P. (1921), f. Amer. med. Ass., 76, 720.

TOPLEY and WILSON (1946), 'Principles of Bacteriology and Immunity,' third edition, p. 902.

WEINSTEIN, L., and WASSERMAN, E. (195I), New Engl. $\mathfrak{7}$. 을 Med., 244, 662.

\section{NOTICE OF SPECIAL INTEREST TO SUBSCRIBERS:}

\section{-WHY NOT HAVE YOUR COPIES OF THIS JOURNAL BOUND INTO YEARLY VOLUMES?'}

You can have your twelve monthly issues fully bound in dark green pin head cloth, lettered in gilt on spine with name of Journal, Volume Number and year, complete with index at front, for 22s. 6d. post free. A limited number of out of print journals are available to bind into volumes and inake your library complete. Price on application giving details of issues required to complete back volumes.

THE FELLOWSHIP OF POSTGRADUATE. MEDICINE 60 PORTLAND PLACE, LONDON, W.I

\section{WHY NOT HAVE YOUR JOURNALS BOUND?}

Bibliography continued from page $483-H$. Ellis, M.Ch., F.R.C.S.

GRIFFITHS, D. Ll. (1940), Brit. F. Surg., 28, 239.

GRIFFITHS, D. Ll. (1948), F. Bone $\mathcal{f}$ Surg., 30b, 280.

HARMAN, J. W. (1947), Amer. F. Path., 23, 55 I.

HORN, J. S., and SEVITT, S. (1951), F. Bone $\mathcal{F}$ Surg., 33b, 348.

HORWITZ, T. (1940), Arch. Surg. (Chicago), 41, 945.

HUGHES, C. W. (1954), Surg. Gynec. Obstet., 99, 9 I.

JONES, S. G., and COTTON, F. J. (1935), F. Bone $\mathcal{F}$ Surg., $17,659$.

KINMONTH, J. B. (1952), Brit. med. F., i, 59.

LAPEYRE, N. C., and CARABALONA, P. (1952), Lyon Chir., 47, 419.

LEARMONTH, J. R. (1943), Proc. roy. Soc. Med., 36, 515.

LE GROS CLARK, W. E. (1945), Lancet, i, 17.

LINDER, J. M., and HARLEY, J. H. (1953), Surgery, 34, $5 \mathrm{I}$.

MACAUSLAND, W. R., GARTLAND, J. J., and HALLOCK, $H$. (1953), F. Bone F Surg., 35a, 604

MACFARLANE, J. A. (1942), Ibid., 24, 739.

MEYERDING, H. W. (1930), F. Amer. med. Ass., 94, 394

MIDDLETON, D. S. (1930), Brit. F. Surg., 18, 188.

MILLER, D. S., MARKIN, L., and GROSSMANN, E. (1952), Amer. $\mathcal{F}$. Surg., 84, 317 .
MURPHY, J. B. (1914), F. Amer. med. Ass., 63, 1,249.

MUSTARD, W. T., and SIMMONS, E. H. (1953), $\mathcal{f}$. Bone $\mathcal{f}$ Surg., 35b, 437 .

PARKES, A. R. (1945), Brit. F. Surg., 32, 403.

PHALEN, G. S. (1948), Ann. Surg., 127, 112.

RICHE, V., AUSSILLOUX, J, and GINESTIE, J. Presse med., 47, 1, 173 .

SALEMBIER, Y. (1954), Lyon Chir., 49, 620.

SEDDON, H. J. (1956), Ұ. Bone 7 Surg., 38b, 152.

SIMMONS, E. H. (1956), Arch. Surg. (Chicago), 73, 625.

SIRBU, A. B., MURPHY, M. J., and WHITE, A. S. (1944), N Calif. west. Med., 60, 53 .

SPENCER, F. C., and GREWE, R. V. (1955), Ann. Surg., 141, 304 O

STANFORD, S. (1944), Lancet, i, 462 . $33 b, 336$.

WATSON-JONES, R. (1952), Fractures and Foint Injuries, $4^{\text {th }}$ ? $^{+}$ edition, $\mathrm{x}, \mathrm{I} 16$.

WILSON, W. C. (1932), Brit. F. Surg., 20, 393. 